\title{
PENGARUH AROMATERAPI LEMON TERHADAP TINGKAT KEJENUHAN KERJA (BURNOUT) PERAWAT INTENSIVE CARE UNIT RUMAH SAKIT UMUM DAERAH SULTAN SYARIF MOHAMAD ALKADRIE KOTA PONTIANAK
}

\author{
THE EFFECT OF LEMON AROMATHERAPY ON JOB BURNOUT (BURNOUT) \\ INTENSIVE CARE UNIT NURSES AT SULTAN SYARIF MOHAMAD ALKADRIE \\ HOSPITAL PONTIANAK CITY \\ Novianita Anggreini*, Rita Hafizah**, Saiman** \\ *Program Studi Keperawatan, Fakultas Kedokteran, Universitas Tanjungpura, \\ Jl. Prof. Dr. H. Hadari Nawawi, Pontianak \\ Email: novianita.anggreini@gmail.com
}

\begin{abstract}
Abstrak
Latar Belakang : Burnout (kejenuhan) merupakan sindrom akibat tekanan berkepanjangan terhadap tekanan kerja yang membawa kepada penarikan diri. Burnout tentunya berdampak macam-macam, baik pada institusi, diri sendiri, maupun keluarga. Keadaan ini membuat pekerja akan kurang memberikan komitmen terhadap kerja. Aromaterapi Lemon dipercaya mengurangi kelelahan mental dan perasaan terbebani atau terbebani oleh tanggung jawab hidup. Minyak lemon sangat membantu untuk menghilangkan emosi reaktif untuk mengembangkan hubungan yang sehat dengan orang lain .

Tujuan : Penelitian ini bertujuan untuk mengetahui Pengaruh Aromaterapi Lemon Terhadap Tingkat Kejenuhan Kerja (Burnout) Perawat ICU RSUD Sultan Syarif Mohamad Alkadrie Kota Pontianak.

Metodologi Penelitian : Penelitian ini bersifat kuantitatif dengan menggunakan desain penelitian Quasi Experiment dengan rancangan One Group Pretest Posttest design tanpa adanya kelompok kontrol. Sampel dalam penelitian ini berjumlah 16 responden yang diberikan aromaterapi lemon. Analisis yang digunakan adalah mengunakan uji Wilcoxon.

Hasil : Hasil menunjukan nilai significancy $0,001(\mathrm{p}<0,05)$. Nilai ini menyatakan bahwa ada pengaruh aromaterapi lemon terhadap kejenuhan kerja (burnout) pada perawat intensive care unit.

Kesimpulan : Ada pengaruh aromaterapi lemon terhadap kejenuhan kerja (burnout) sebelum dan sesudah diberikan intervensi. Aromaterapi lemon dapat menurunkan tingkat kejenuhan pada perawat intensive care unit.
\end{abstract}

Kata Kunci : Perawat, Burnout, Aromaterapi Lemon 


\begin{abstract}
Background: Burnout is a syndrome due to prolonged pressure on the work pressure that leads to withdrawal. Burnout certainly has an impact on things, both in institutions, self, and family. This situation makes workers less committed to work. Lemon Aromatherapy is believed to reduce mental fatigue and feelings of being burdened or burdened by life's responsibilities. Lemon oil is very helpful to eliminate reactive emotions to develop healthy relationships with others.

Purpose: This research is to understand the effects of lemon aromatherapy on the decrease of burnout on intensive care unit nurses at sultan syarif mohamad alkadrie hospital pontianak city.

Methods: This research is a quantitative research by using design research quasi experiment program with one group pretest-posttest design without any other group control. The sample of this research are 16 respondents given lemon aromatherapy. The analysis is used Wilcoxon Test. Result: The result showed significant value 0,001 $(p<0.05)$. The value showed that there is an influence effect of lemon aromatherapy on the decrease of burnout on intensive care unit nurses. Conclusion: There is an influence effect of lemon aromatherapy on the decrease of burnout on intensive care unit nurses before and after given intervention.
\end{abstract}

Keywords: Nurse, burnout, lemon aromatherapy

\author{
*Nursing Student Tanjungpura University \\ **Nursing Lecture Tanjungpura University
}




\section{PENDAHULUAN}

Rumah sakit merupakan salah satu bagian dari sarana kesehatan yang diselenggarakan oleh pemerintah maupun swasta. Rumah sakit dalam menjalankan fungsinya diharapkan dapat memperhatikan fungsi sosial dalam memberikan pelayanan kesehatan kepada masyarakat. Keberhasilan rumah sakit ini ditandai dengan berkualitasnya mutu pelayanan oleh pihak rumah sakit yang dipengaruhi oleh beberapa faktor, yakni yang paling dominan adalah Sumber Daya Manusia (SDM), berupa tenaga medis (dokter, perawat) dan non medis (Nugroho, 2011).

Dalam Undang-Undang Nomor 44 Tahun 2009 mengenai rumah sakit disebutkan rumah sakit adalah institusi pelayanan kesehatan perorangan secara paripurna (promotif, preventif, kuratif, dan rehabilitatif) dengan menyediakan pelayanan rawat inap, rawat jalan, dan gawat darurat (Hartono, 2010). Unit pelayanan rawat inap dirumah sakit salah satunya yakni Intensive Care Unit (ICU) merupakan bagian dari bangunan rumah sakit yang merawat pasien dalam keadaan belum stabil sesudah operasi berat atau bukan karena operasi berat yang memerlukan pemantauan ketat secara intensif atau tindakan segera selama 24 jam dikarenakan kondisi yang sedang kritis atau mengancam jiwa (Kemenkes, 2010).

Perawat merupakan salah satu komponen dalam pelayanan rumah sakit yang menjadi tolak ukur yang menentukan pelayanan rumah sakit yang dituntut profesionalisme dalam menjalankan tugas perawatan individu, keluarga, dan masyarakat berbentuk pelayanan komprehensif sehingga mereka dapat mencapai, mempertahankan, atau memulihkan kesehatan yang optimal serta kualitas hidup dari lahir sampai mati
(Rahayu, 2013). Perawat ICU telah mendapatkan pelatihan khusus berupa Basic Life Support (BLS) dan Advanced Cardiac Life Support (ACLS) (Depkes RI, 2006). Keahlian khusus meliputi kemampuan menangani kondisi pasien yang kritis, bekerja dengan cepat, tepat, teliti, dan cermat dalam mengobservasi dan menilai keadaan umum pasien yang cenderung fluktuatif (Jusnimar, 2012).

Burnout (kejenuhan) merupakan sindrom akibat tekanan berkepanjangan terhadap tekanan kerja yang membawa kepada penarikan diri. Burnout tentunya berdampak macam-macam, baik pada institusi, diri sendiri, maupun keluarga. Keadaan ini membuat pekerja akan kurang memberikan komitmen terhadap kerja dan mulai mempunyai perasaan hendak lari (Abu Bakar, 2012).

Menurut Kleiber \& Ensman, bibliografi terbaru yang memuat 2496 publikasi mengenai burnout di Eropa menunjukkan $43 \%$ burnout pada pekerja kesehatan dan sosial (perawat), 32\% pada guru (pendidik), 9\% pada pekerja administrasi dan manajemen, $4 \%$ pada pekerja di bidang hukum dan kepolisian, dan $2 \%$ pada pekerja lainnya. Dari persentase di atas dapat dilihat bahwa profesi perawat menempati urutan tertinggi sebagai profesi dengan masalah burnout. Dari jumlah keseluruhan pekerja yang mengalami burnout hampir setengahnya adalah perawat (Prestiana, 2012).

Tugas dan tanggung jawab perawat bukan hal yang ringan untuk dipikul, disatu sisi perawat bertanggungjawab dengan tugas fisik, administratif, dari instansi tempat ia bekerja, menghadapi kecemasan, keluhan dan mekanisme pertahanan diri pasien akibat sakitnya, ketegangan, kejenuhan dalam menghadapi pasien dalam kondisi sakit kritis atau dengan keadaan terminal, 
dan ia juga dituntut untuk selalu tampil sebagai profil perawat yang baik oleh pasiennya (Danang, 2009).

Beberapa riset dengan penggunaan minyak aroma dapat mengungkapkan fakta bahwa bau memiliki dampak penting pada perasaan (Sharma, 2009). Aromaterapi adalah terapi penggunaan wewangian berupa minyak esensial dari tumbuh-tumbuhan yang juga dapat dikombinasikan dengan minyak campuran obat (base oil). Aromaterapi sangat bermanfaat bagi kesehatan diantaranya membantu menghilangkan kelelahan fisik, ketegangan pikiran yang berlebihan, memberikan rasa nyaman dan segar, mengurangi kecemasan dan mengatasi insomnia. Melalui proses inhalasi, sifat minyak sari dapat menstimulasi sistem penghidu yang menghantarkan pesan ke otak, melepaskan berbagai neurokimiawi seperti relaksasi, stimulan, sedatif dan sifat eforik yakni menimbulkan rasa senang (Dewi, 2011).

Studi yang dilakukan oleh The Ohio State University menyatakan bau lemon merangsang dan mengaktifkan yang membuat subjek merasa lebih waspada dan berenergi. Subjek yang terkena aroma minyak esensial lemon secara konsisten mempengaruhi suasana hati menjadi lebih baik dan lebih positif, meningkatkan kinerja tugas mental dan fisik, menunjukkan efek fisik dan emosional yang berpengaruh baik terhadap otak (Glaser et al., 2008).

Zat yang terkandung dalam lemon (Citrus limon) salah satunya adalah linalool yang berguna untuk menstabilkan sistem saraf sehingga dapat menimbulkan efek tenang bagi siapapun yang menghirupnya (Wong, 2010). Minyak esensial lemon (Citrus limon) berkhasiat meremajakan, membangkitkan rasa senang, menyejukkan, dan membangkitkan semangat. (Jaelani, 2009)

\section{METODE}

Penelitian yang dilakukan yaitu penelitian yang bersifat kuantitatif dengan menggunakan desain penelitian preeksperimental dengan rancangan One Group Pretest Posttest design tanpa adanya kelompok kontrol.

Penelitian ini telah dilakukan selama 3 hari dengan mengukur skor burnout pada perawat ICU menggunakan Maslach Burnout Inventory-Human Services Survey (MBI-HSS) 3 hari sebelum diberikan aromaterapi lemon dan kemudian telah diukur kembali skor burnoutnya setelah dilakukan pemberian aromaterapi lemon dengan menggunakan instrumen yang sama.

Sampel pada penelitian ini adalah seluruh perawat ICU yang mengalami burnout di ICU Rumah Sakit Umum Daerah Sultan Syarif Mohamad Alkadrie di Kota Pontianak. Teknik pengambilan sampel dalam penelitian ini adalah Purposive Sampling. Sampel dalam penelitian ini adalah 16 orang. Tempat penelitian ini dilakukan di ICU Rumah Sakit Umum Daerah Sultan Syarif Mohamad Alkadrie di Kota Pontianak di Jalan Komyos Sudarso selama 6 hari pada tanggal 11 Juli 2018 sampai 16 Juli 2018.

Kriteri inklusi dalam penelitian ini yaitu perawat di ruang ICU RSUD Sultan Syarif Mohamad Alkadrie Kota Pontianak, perawat ICU dengan kategori burnout rendah hingga sangat tinggi, bersedia menjadi sampel dalam penelitian dengan menandatangani informed concent.

Sedangkan kriteria eksklusi dalam penelitian ini adalah perawat yang cuti lebih dari tiga bulan dan responden yang mengikuti pelatihan dan pendidikan lebih dari 1 bulan selama penelitian dan responden dengan skor 0.0-19.2 = burnout sangat rendah. 
Variabel terikat dalam penelitian ini yaitu burnout dengan skor Maslach Burnout Inventory-Human Services Survey (MBI$H S S$ ) sedangkan variabel bebasnya yaitu intervensi aromaterapi lemon.

\section{HASIL}

Distribusi Karakteristik

Berdasarkan Usia, Jenis Kelamin, Status

Perkawinan, Pendidikan, Masa Kerja di ICU

\begin{tabular}{|c|c|c|c|}
\hline $\begin{array}{c}\text { Karakteristik } \\
\text { Responden }\end{array}$ & & $\begin{array}{l}\text { Frekuensi } \\
\text { (F) }\end{array}$ & $\begin{array}{c}\text { Persen } \\
(\%)\end{array}$ \\
\hline \multirow{2}{*}{ Usia } & 26-35 tahun & 14 & $87.5 \%$ \\
\hline & $36-45$ tahun & 2 & $12.5 \%$ \\
\hline \multirow{2}{*}{ Jenis Kelamin } & Laki-laki & 6 & $37.5 \%$ \\
\hline & Perempuan & 10 & $62.5 \%$ \\
\hline Status & Menikah & 10 & $62.5 \%$ \\
\hline Perkawinan & Belum Menikah & 6 & $37.5 \%$ \\
\hline \multirow{3}{*}{ Pendidikan } & D3 & 9 & $56.2 \%$ \\
\hline & D4 & 1 & $6.2 \%$ \\
\hline & S1/Profesi & 6 & $37.5 \%$ \\
\hline \multirow{3}{*}{ Masa Kerja } & $<1$ tahun & 2 & $12.5 \%$ \\
\hline & $1-5$ tahun & 12 & $75 \%$ \\
\hline & $>5$ tahun & 2 & $12.5 \%$ \\
\hline Total & & 16 & $100 \%$ \\
\hline
\end{tabular}

Berdasarkan hasil analisis pada Tabel diatas dapat dilihat bahwa jumlah responden terbanyak adalah berusia 26-35 tahun dengan jumlah responden 14 responden $(87.5 \%)$ berjenis kelamin perempuan yaitu sebanyak 10 responden (62.5\%). Status perkawinan yakni menikah sebanyak 10 responden (62.5\%). Tingkat pendidikan responden di ICU RSUD Sultan Syarif Mohamad Alkadrie Kota Pontianak yang terbanyak yaitu D3 dengan jumlah 9 responden $(56.2 \%)$. Masa kerja di ICU RSUD Sultan Syarif Mohamad Alkadrie Kota Pontianak yakni 1-5 tahun sebanyak 12 responden $(75 \%)$
Karakteristik Responden Berdasarkan Skor Burnout pada Pretest dan Posttest

\begin{tabular}{ccccc}
\multirow{2}{*}{$\begin{array}{c}\text { Rentang } \\
\text { Skor }\end{array}$} & \multicolumn{2}{c}{ Pretest } & \multicolumn{2}{c}{ Posttest } \\
\cline { 2 - 5 } & $\begin{array}{c}\text { Frekuensi } \\
(\mathbf{F})\end{array}$ & $\begin{array}{c}\text { Persen } \\
(\%)\end{array}$ & $\begin{array}{c}\text { Frekuensi } \\
(\mathbf{F})\end{array}$ & $\begin{array}{c}\text { Persen } \\
(\%)\end{array}$ \\
\hline $0.0-19.2$ & 0 & $0 \%$ & 4 & $25 \%$ \\
\hline $19.2-38.4$ & 14 & $87.5 \%$ & 12 & $75 \%$ \\
\hline $38.4-57.6$ & 2 & $12.5 \%$ & 0 & $0 \%$ \\
\hline $57.6-76.8$ & 0 & $0 \%$ & 0 & $0 \%$ \\
\hline $76.8-96$ & 0 & $0 \%$ & 0 & $0 \%$ \\
\hline Total & 16 & $100 \%$ & 16 & $100 \%$ \\
\hline
\end{tabular}

Berdasarkan hasil analisis pada Tabel didapatkan skor burnout sebelum dan sesudah dilakukannya aromaterapi lemon terhadap perawat ICU di RSUD Sultan Syarif Mohamad Alkadrie Kota Pontianak didapatkan hasil skor burnout pada pretest dimulai dari skor 19.2-57.6. Skor tertinggi adalah 38.4-57.6 sebanyak 2 responden (12.5\%). Skor burnout pada posttest dimulai dari skor 0.0-38.4. Skor tertinggi adalah 19.2-38.4 sebanyak 12 responden (75\%).

Distribusi Karakteristik Responden Berdasarkan Tingkat Burnout pada Pretest dan Posttest

\begin{tabular}{ccccc}
\hline \multirow{2}{*}{$\begin{array}{c}\text { Tingkat } \\
\text { Burnout }\end{array}$} & $\begin{array}{c}\text { Prekuensi } \\
\text { (F) }\end{array}$ & $\begin{array}{c}\text { Persen } \\
(\%)\end{array}$ & $\begin{array}{c}\text { Frekuensi } \\
\text { (F) }\end{array}$ & $\begin{array}{c}\text { Persen } \\
(\%)\end{array}$ \\
\hline $\begin{array}{c}\text { Burnout } \\
\text { sangat } \\
\text { rendah } \\
(0.0-19.2)\end{array}$ & 0 & $0 \%$ & 4 & $25 \%$ \\
\hline $\begin{array}{c}\text { Burnout } \\
\text { rendah }\end{array}$ & 14 & $87.5 \%$ & 12 & $75 \%$ \\
$(19.2-38.4)$ & & & & \\
\hline $\begin{array}{c}\text { Burnout } \\
\text { cukup } \\
(38.4-57.6)\end{array}$ & 2 & $12.5 \%$ & 0 & $0 \%$ \\
\hline $\begin{array}{c}\text { Burnout } \\
\text { tinggi } \\
(57.6-76.8\end{array}$ & 0 & $0 \%$ & 0 & $0 \%$ \\
\hline $\begin{array}{c}\text { Burnout } \\
\text { sangat tinggi } \\
(57.6-76.8)\end{array}$ & 0 & $0 \%$ & 0 & $0 \%$ \\
\hline Total & 16 & $100 \%$ & 16 & $100 \%$ \\
\hline
\end{tabular}


Berdasarkan hasil analisis dari Tabel di atas didapatkan data bahwa sebanyak 14 responden $(87,5 \%)$ memiliki tingkat burnout rendah sebelum diberikan aromaterapi lemon dan 2 responden (12,5\%) memiliki tingkat burnout cukup sebelum diberikan aromaterapi lemon. Sebanyak 12 responden (75\%) memiliki tingkat burnout rendah sesudah diberikan aromaterapi lemon dan 4 responden (25\%) tingkat burnoutnya sangat rendah setelah diberikan aromaterapi lemon.

Hasil uji Wilcoxon dapat dilihat pada Tabel di bawah ini.

\begin{tabular}{c|c|c}
\hline Variabel & N & $\begin{array}{c}\text { Asymp. Sig. } \\
\text { (2-tailed) }\end{array}$ \\
\hline $\begin{array}{c}\text { Skor Burnout Sebelum } \\
\text { Skor Burnout Sesudah }\end{array}$ & 16 & 0.000 \\
\hline
\end{tabular}

Berdasarkan Tabel di atas, dapat disimpulkan bahwa nilai $\mathrm{p}(0,000)<0,05$ yang artinya $\mathrm{H}_{0}$ ditolak dan ada pengaruh terapi Aromaterapi Lemon terhadap penurunan skor burnout perawat di ICU RSUD Sultan Syarif Mohamad Alkadrie Kota Pontianak setelah diberikan perlakuan.

\section{PEMBAHASAN}

\section{Karakteristik Responden Berdasarkan Jenis Kelamin}

Responden pada penelitian ini didominasi oleh perawat dengan jenis kelamin perempuan sebanyak 10 orang (62.5\%) sedangkan perawat dengan jenis kelamin laki-laki sebanyak 6 orang (37.5\%). Hasil penelitian ini menunjukkan bahwa perempuan lebih banyak mengalami burnout, para perawat perempuan mengalami kelelahan dan kesulitan menyeimbangkan pekerjaan dan kehidupan keluarga, tidak jarang perawat perempuan harus meninggalkan keluarga yang sedang sakit atau membutuhkan perhatian lebih dan disisi lain mereka juga harus bersikap professional mengutamakan menolong dan menghibur pasien, letih bekerja lembur saat dinas malam, serta dalam bekerja cenderung mengikuti perasaannya.

Hal ini sejalan dengan penelitian yang dilakukan Ramdan (2016) penelitian tentang perbedaan kelelahan kerja (burnout) antara perawat laki-laki dan perawat perempuan ditemukan terdapat perbedaan yang signifikan yakni burnout yang dialami perawat perempuan lebih tinggi dibanding perawat laki-laki yang disebabkan oleh beberapa kemungkinan antara lain disebabkan karena perawat perempuan mengalami konflik antara mengurus keluarga dan menolong pasien secara professional yang sudah menjadi tanggungjawabnya. Hasil penelitian ini sesuai dengan penelitian Guillermo et al., (2015) yang menyimpulkan bahwa, jenis kelamin, status pernikahan dan kepemilikan anak berhubungan signifikan dengan burnout pada perawat

\section{Karakteristik Responden Berdasarkan Usia}

Hasil yang didapatkan dalam penelitian ini adalah usia responden yang paling banyak mengalami burnout yakni usia dewasa awal (26-35 tahun) dengan jumlah 14 orang (87.5\%). Perawat yang memiliki usia muda masih minim pengalaman dan pengetahuan dalam menangani pasien, terkadang masih memerlukan adaptasi dengan lingkungan pekerjaan. Hasil penelitian ini sejalan dengan penelitian Suharti (2013) umur berpengaruh terhadap kemampuan 
mengatasi masalah dalam pekerjaan yang berpengaruh terhadap burnout. Faktor yang menjadi penyebab ada hubungan umur dengan burnout dikarenakan emosional, harapan yang tinggi terhadap cita-cita, idealisme, terlalu banyak tuntutan sehingga dalam bekerja mereka yang menjadikannya lebih rentan mengalami gejala burnout. Seperti yang dikemukakan oleh Maslach (1982 dalam Caputo 1991) mengatakan bahwa orang usia muda memiliki kemungkinan mengalami burnout lebih besar daripada orang usia lebih tua. Burnout paling sering terjadi pada karyawan muda dengan usia dibawah 30 tahun yang mempunyai pengalaman pekerjaan yang relatif sedikit. Para pekerja pemberi pelayanan di usia muda dipenuhi dengan harapan yang tidak realistik jika dibandingkan dengan mereka yang berusia lebih tua. Seiring dengan pertambahan usia pada umumnya individu menjadi lebih matang, lebih stabil, lebih teguh sehingga memiliki pandangan yang lebih realistis.

\section{Karakteristik Responden Berdasarkan Status Perkawinan}

Hasil yang didapatkan dari penelitian ini adalah status perkawinan responden yang paling banyak yakni menikah sebanyak 10 responden $(62.5 \%)$. Perawat yang menikah memiliki masalah tersendiri yang terkadang terbawa saat bekerja yakni permasalahan rumah tangga dan tuntutan serta tanggung jawab yang besar terhadapnya cenderung memberikan pengaruh cukup besar dalam kejenuhan kerja. Sehingga orang yang sudah menikah lebih banyak memiliki beban pikiran Tingkat burnout yang lebih banyak dialami perawat yang sudah menikah menurut Sari (2015), hal ini dimungkinkan terjadi karena orang yang sudah menikah akan memiliki tanggung jawab terhadap keluarga dan pekerjaan berbeda dengan seseorang yang belum menikah yang bisa fokus terhadap pekerjaannya. Pada penelitian Tipadjan dan Sundaram (2012) yang menyimpulkan dukungan sosial dari keluarga dan rekan kerja berhubungan signifikan dengan burnout pada perawat.

\section{Karakteristik Responden Berdasarkan Tingkat Pendidikan}

Hasil yang didapatkan dari penelitian ini adalah tingkat pendidikan Diploma III sebanyak 9 responden (56.2\%) yang mengalami burnout paling banyak. Perawat yang pendidikannya lebih rendah mengalami stres karena pengalaman dan pendidikan yang didapat tidak sebanyak yang menjadi lulusan S1. Hal ini sejalan dengan penelitian Sari (2015) yang menyatakan tingkat pendidikan yang rendah jika dihadapkan dengan tugas dan beban kerja yang melebihi kapabilitasnya cenderung akan meningkatkan stres dan mengalami burnout. Teori Pearlman dan Hartman yang mengatakan hubungan antara persepsi dengan dampak stres kerja pada karyawan. Teori ini memprediksi bahwa ketika harapan dan nilai-nilai karyawan tidak sesuai dengan harapan dan nilai-nilai organisasi, karyawan tersebut jauh lebih mungkin untuk meningkatkan gejala burnout (Mbuthia, 2009).

\section{Karakteristik Responden Berdasarkan Masa Kerja}

Hasil yang didapatkan dalam penelitian ini adalah masa kerja yang paling banyak mengalami burnout yakni 1-5 tahun dengan jumlah 12 responden (75\%). Dengan 
masa kerja yang masih minim perawat masih belum cukup terbiasa dengan pekerjaannya, pengalaman yang masih minim, dan masih membutuhkan bimbingan dari perawat senior terutama perawat dengan masa kerja kurang dari 1 tahun. Hasil penelitian ini sejalan dengan penelitian Suharti (2013) yang menyatakan ditemukan perbedaan berarti pada masa kerja dengan burnout yakni masa kerja yang sedikit cenderung megalami burnout dikarenakan belum sepenuhnya menguasai pekerjaan. Menurut Maslach (2008) kejenuhan kerja (burnout) ini cenderung dirasakan pada karyawan dengan lama kerja yang dini, karena semakin lama karyawan bekerja ia akan semakin terbiasa dengan pekerjaannya, sedangkan untuk karyawan yang baru memulai menguasai pekerjaannya secara tidak langsung dapat menjadi beban dan stress pada pegawai baru yang pada akhirnya dapat menyebabkan kejenuhan dalam bekerja.

\section{Pengaruh Aromaterapi Lemon Terhadap Tingkat Kejenuhan Kerja (Burnout) Perawat Intensive Care Unit}

Dari penelitian ini maka terlihat bahwa ada pengaruh Aromaterapi Lemon Terhadap Tingkat Kejenuhan Kerja (Burnout) Perawat Intensive Care Unit RSUD Sultan Syarif Mohamad Alkadrie di Kota Pontianak, yang terlihat dari penurunan skor sebelum dan sesudah diberikannya aromaterapi lemon dengan rentang skor burnout 19.2 - 57.6 pada pretest dan skor burnout dalam rentang 0.0 - 38.4 pada posttest. Berdasarkan hasil uji Wilcoxon juga didapatkan bahwa nilai $\mathrm{p}$ $(0.000) \leq 0.05$. Penurunan skor burnout dalam penelitian ini bervariasi dan dipengaruhi banyak faktor, seperti tingkat konsentrasi dan fokus selama mengikuti terapi di setiap harinya. Hasil penelitian ini juga serupa dengan penelitian yang dilakukan Varney \& Buckle tentang pengaruh inhalasi minyak esensial pada kelelahan mental dan burnout menggunakan inhaler pribadi dengan campuran aromaterapi (peppermint, basil, dan helichrysum) selama 3 hari. Dengan hasil menunjukkan bahwa menghirup minyak esensial oil beberapa hari dapat mengurangi tingkat kelelahan mental / kejenuhan yang dirasakan. (Varne dan Buckle, 2013). Dan penelitian Evanjelis tentang "Pengaruh Aromaterapi Lemon (Citrus Limon) Terhadap Waktu Reaksi Sederhana Pria Dewasa" menggunakan alat pengukur waktu reaksi yaitu kronoskop yang dilakukan sebelum dan sesudah subjek penelitian menghirup aromaterapi lemon (Citrus limon). Pengaruh aromaterapi lemon (Citrus Limon) terhadap waktu reaksi diuji menggunakan uji "t" berpasangan dan diperoleh nilai $\mathrm{p}<0,01$ (sangat signifikan). Dapat disimpulkan bahwa pengaruh aromaterapi lemon (Citrus Limon) sangat bermakna (Evanjelis, 2015).

Hasil penelitian ini sesuai dengan teori, dimana bau berpengaruh langsung terhadap otak manusia, seperti narkotika. Minyak atsiri (essential oil) merupakan zat serbaguna. Molekul yang dilepaskan ke udara adalah sebagai uap yang dibawa oleh uap air. Ketika uap air yang mengandung komponen kimia tersebut dihirup, akan diserap tubuh melalui hidung dan paru-paru yang kemudian masuk ke aliran darah. Bersamaan saat dihirup itu, uap air akan berjalan dengan segera ke sistem limbik otak yang bertanggung jawab dalam sistem 
integrasi dan ekspresi perasaan, belajar, ingatan, emosi, serta rangsangan fisik (Jaelani, 2009). Minyak lemon menunjukkan efek anti stress terkuat sebagai anti depresan untuk mempercepat laju metabolisme yang diatur oleh hippocampus untuk menghasilkan pemikiran rasional. Minyak lemon ditunjuk untuk menghubungkan pemicu emosional, memberi energi dan menyegarkan tubuh dan pikiran ,dan meningkatkan kemampuan untuk fokus dan menghafal, serta membantu saat dibutuhkan kejelasan untuk membuat keputusan. Secara psikologis, bau minyak lemon mengurangi kelelahan mental dan perasaan terbebani atau terbebani oleh tanggung jawab hidup. Minyak lemon sangat membantu untuk menghilangkan emosi reaktif untuk mengembangkan hubungan yang sehat dengan orang lain (Stiles, 2017).

\section{IMPLIKASI KEPERAWATAN}

Setelah dilakukan penelitian ini didapatkan hasil bahwa terdapat pengaruh Aromaterapi Lemon Terhadap Tingkat Kejenuhan Kerja (Burnout) Perawat ICU RSUD Sultan Syarif Mohamad Alkadrie Kota Pontianak. Oleh karena itu aromaterapi lemon dapat dijadikan sebagai salah satu terapi pendamping untuk menurunkan tingkat kejenuhan kerja perawat. Aromaterapi lemon ini juga dapat dijadikan terapi mandiri karena pemberian aromaterapi ini merupakan terapi yang aman dan mudah dilakukan. Untuk itu aromaterapi lemon dapat dijadikan sumber referensi tentang terapi komplementer (pendamping) dalam memberikan asuhan keperawatan kepada perawat dengan tingkat kejenuhan kerja (burnout).

\section{KESIMPULAN}

1. Ada pengaruh aromaterapi lemon terhadap penurunan skor kejenuhan kerja (burnout) sebelum dan sesudah dilakukan intervensi dengan rata-rata skor burnout sebelum dilakukan terapi adalah 19.2 - 57.6 dan mengalami penurunan menjadi $0.0-38.4$ setelah dilakukan pemberian aromaterapi lemon.

2. Dari hasil penelitian didapatkan karakteristik perawat ICU RSUD Sultan Syarif Mohamad Alkadrie sebanyak 21 orang dan yang dijadikan responden berjumlah 16 responden. Responden tersebut berjenis kelamin perempuan sebanyak 10 responden dan 6 responden berjenis kelamin laki-laki dengan usia terbanyak yaitu rentang usia antara 1925 tahun (dewasa awal), status perkawinan terbanyak yakni sudah menikah, dan tingkat pendidikan perawat ICU terbanyak yaitu diploma III, serta masa kerja di ruang ICU dari responden terbanyak adalah 1-5 tahun.

3. Dari hasil penelitian tingkat kejenuhan kerja (burnout) perawat ICU RSUD Sultan Syarif Mohamad Alkadrie Kota Pontianak saat pretest 14 responden mengalami burnout rendah dan 2 responden mengalami burnout cukup.

4. Dari hasil penelitian tingkat kejenuhan kerja (burnout) perawat ICU RSUD Sultan Syarif Mohamad Alkadrie Kota Pontianak setelah dilakukannya pemberian aromaterapi lemon dan setelah dilakukan posttest ditemukan 4 responden burnout sangat rendah dan 12 responden mengalami burnout rendah. 


\section{SARAN}

1. Bagi RSUD Sultan Syarif Mohamad Alkadrie Kota Pontianak

Hasil dari penelitian ini diharapkan dapat membantu dalam mendeteksi dan menangani perawat dengan kejenuhan kerja (burnout) yang berada di RSUD Sultan Syarif Mohamad Alkadrie Kota Pontianak dengan pengadaan aromaterapi lemon pada setiap ruangan dengan beban kerja yang tinggi seperti ICU, IGD, dan OK yang dilakukan secara berkala sebagai upaya preventif dan promotif. Serta diperlukan pengadaan program refreshing (seperti out bond) terhadap perawat agar tidak mengalami kejenuhan (burnout) yang berkepanjangan yang dapat memengaruhi performa dalam bekerja.

2. Bagi Peneliti Selanjutnya

Hasil dari penelitian ini diharapkan agar dapat memperkaya konsep atau teori yang dapat menyokong dalam mengembangkan pengetahuan dan pengalaman terhadap terapi komplementer yang dapat digunakan kepada perawat yang mengalami kejenuhan kerja (burnout).

\section{DAFTAR PUSTAKA}

1. Nugroho, A. (2011). Studi Deskriptif Burnout dan Coping Stres pada Perawat. Jurnal Ilmiah Mahasiswa Universitas Surabaya Vol. $1,1$.

2. Hartono. (2010). Manajemen Pemasaran untuk Rumah Sakit. Jakarta: Rineka Cipta.
3. Kementerian Kesehatan RI, (2010). Pedoman Teknis Ruang Perawatan Intensif Rumah Sakit. Jakarta: Direktorat Bina Pelayanan Penunjang Medik dan Sarana Kesehatan

4. Rahayu, I. (2013). Tingkat Kepuasan Klien Akan Pola Komunikasi Terapeutik oleh Perawat di Rumah Sakit Bhayangkara Polda Kalbar. Pontianak: ProNers Jurnal Keperawatan Vol. 1 No. 1

5. Depkes RI (2006). Standar Pelayanan Keperawatan ICU. Direktorat Keperawatan dan Keteknisian Medik Direktorat Jendral Pelayanan Medik Jakarta: Depkes RI

6. Jusnimar. (2012). Gambaran Tingkat Stress Kerja Perawat Intensive Care Unit (ICU) di Rumah Sakit Kanker Dharmais. Depok: FKIK UI

7. Abu Bakar, A. (2012). Psikologi Industri dan Pegurusan Sumber Manusia. Malaysia: Universiti Malaysia Terengganu

8. Prestiana, N. D., \& Purbandini, D. (2012). Hubungan antara Efikasi Diri (Self Efficacy) dan Stres Kerja dengan Kejenuhan Kerja (Burnout) Pada Perawat IGD Dan ICU RSUD Kota Bekasi. Jurnal Soul, Vol. 5, No.2.

9. Danang, P. (2009). Hubungan Stress Kerja dengan Adaptasi Pada Perawat di Instalasi Gawat Darurat RSUD Pandan Arang Boyolali.Universitas Muhammadiyah, Fakultas Ilmu Kesehatan, Surakarta, (Skripsi)

10. Sharma, Sumeet. (2009). Aromaterapi. Tanggerang: Karisma Publishing Group

11. Dewi, Iga Prima. (2011). Aromaterapi Lavender Sebagai Media Relaksasi. Bali: Bagian Farmasi Fakultas Kedokteran 
Universitas Udayana. Diunduh tanggal 9 April 2015

12. Glaser, J. K. ,Graham, J.E., Malarkey, W. B., Porter, K., Lemeshow, S., and Glaser, R. (2008). Olfactory Influences on Mood and Autonomic, Endocrine, and Immune Function. Columbus: Psychoneuroendocrinology Vol. 33

13. Wong. (2010). Easing anxiety with aromatherapy. about.com alternative medicine [Electronic version]. Diperoleh tanggal 5 Juni 2016 dari http://altmedicine.about.com/od/anxi ety/a/anxiety acupuncture.htm

14. Jaelani. (2009). Aroma Terapi. Jakarta: Pustaka Populer Obor

15. Ramdan, Iwan M. (2016). Analisis Faktor yang Berhubungan dengan Burnout pad Perwat Kesehatan Jiwa. Samarinda: FKM Mulawarman.

16. Guillermo, A., Cañadas-De la Fuente, Vargas, C., Luis, C.S., García, I., Cañadas, G.R., \& De la Fuente, E.I. (2015). Risk factors and prevalence of burnout syndrome in the nursing profession. International Journal for Nursing Studies, 52(1), 240-249.

17. Suharti, Neli. (2013). Burnout Dengan Kinerja Perawat Di Rumah Sakit Metropolitan Medical Centre Jakarta. Jakarta : FKIK UI

18. Caputo, J.S. (1991). Stres and Burnout in Library Service. Phoenix: Oryx Press.

19. Sari, Ika Kasmita. (2015). FaktorFaktor yang Berhubungan dengan Burnout Perawat di RSUD Haji Makassar Tahun 2015. Makassar: UIN Alauddin

20. Tipajan, A., \& Sundaram, S. (2012). Nurses burnout: Does personality and social support relate?. Journal of
Organisation \& Human Behaviour, 1(3).

21. Mbuthia, M. N. (2009). An Investigation Into The Factors that Nurses Working in Critical Care Units Perceive as Leading to Burnout. Dissertation. University Of South Africa

22. Maslach, C. and Leiter, M. P. (2008). Early Predictors of Job Burnout and Engagement. Journal of Applied Psychology, 93, 498-512.

23. Varney,Elizabeth And Buckle, Jane (2013). Effect Of Inhaled Essential Oils On Mental Exhaustion. The Journal of Alternative And Complementary Medicine Volume 19, Number 1, Pp. 69-71

24. Evanjelis, D. (2014). Pengaruh Aromaterapi Minyak Lemon Pada Laki-Laki Dewasa. Bandung: Universitas Kristen Maranatha

25. Stiles, KG. (2017) The Essential Oils Complete Reference Guide Over 250 Recipes for Natural Wholesome Aromateraphy. Massachusetts: Page Street Publishing Co. 